\title{
PENGGUNAAN STRATEGI TEAMS GAMES TOURNAMEN (TGT) UNTUK MENINGKATKAN HASIL BELAJAR PENDIDIKAN AGAMA ISLAM( PAI ) SISWA KELAS XI IPS 3 SMA NEGERI 1 SALO
}

\author{
(Improving Learning Outcomes of Learners Using Cooperative Learning Model Three - Step Interview on the \\ Geometry Room in Class XII MIPA 2 SMA Negeri 2 Pekanbaru)
}

\section{Oleh: Hazmiati, M.Pd.I *)}

*) Guru Pendidikan Agama Islam (PAI) SMA Negeri 1 Salo

\begin{abstract}
Classroom action research has been carried out at SMA Negeri 1 Salo in the subjects of Islamic Religion Education (PAI) with the object of research of class XI IPS 3 students in odd semester 2016/2017. This research was conducted in an effort to improve the PAI learning outcomes for students of class XI IPS 3. Teams Games Tournament (TGT) learning model was chosen to be applied after going through the results of observation and reflection conducted by researchers. Researchers plan actions based on the results of observations and reflections that have been made through the preparation of learning-based learning tools Teams Games Tournament (TGT) which consists of test questions, observation sheets and learning plans and other supporting learning tools. Teams Games Tournament (TGT) learning model consists of 3 main stages: knowing the material, working on the activity sheet, and playing academic games. This research can be completed in 2 cycles of 6 meetings and post tests at the end of each meeting. The results of the study which are observational data and recapitulation of results and recapitulation of learning completeness shows that there has been an increase in positive student learning activities in the classroom and an increase in the mean of the test and an increase in classical completeness of cycle 1 with cycle 2. The average pre-action score is 42.72 (enough) The average value in cycle 1 is 51.84 (enough). The average score in cycle 2 was 76.16 (good). The activity of students during the learning process was observed by observers as data for evaluation and reflection. The recapitulation of the average test and the completeness of the study was obtained from the post test scores of cycles I and II. Based on the results of the study, it can be concluded that the implementation of the Tams Games Tournament (TGT) strategy in class XI IPS 3 of SMA Negeri 1 Salo is able to improve the learning outcomes of PAI subjects (Islamic Education) as indicated by the average test and classical completeness in each cycle.
\end{abstract}

Keywords: Teams Games Tournamen (TGT), students' outpu PAI ( Pendidikan Agama Islam), Mean score and Mastery Learning

\section{PENDAHULUAN}

Mata pelajaran Pendidikan Agama Islam (PAI) secara keseluruhannya dalam lingkup Al - Qur'an dan Al - hadits, keimanan, akhlak, fiqh/ibadah, dan sejarah, sekaligus menggambarkan bahwa ruang lingkup Pendidikan Agama Islam (PAI) mencakup perwujudan keserasian, keselarasan dan keseimbangan hubungan manusia dengan Allah SWT, diri sendiri, sesama manusia, makhluk hidup lainnya maupun lingkungannya. Jadi Pendidikan Agama Islam (PAI) merupakan usaha sadar yang dilakukan pendidik (guru) dalalm rangka mempersiapkan peserta didik untuk menyakini, memahami, dan mengamalkan ajaran Islam melalui kegiatan bimbingan, pengajaran atau 
pelatihan yang telah ditentukan untuk mencapai tujuan yang telah ditetapkan.

Materi Pendidikan Agama Islam (PAI) kelas XI IPS dalam Kurikulum Tingkat Satuan Pendidikan (KTSP) 2006 pada semester 1 antara lain adalah meningkatkan keimanan kepada rasul - rasul Allah dan membiasakan perilaku terpuji..Pada standar kompetensi meningkatkan keimanan kepada rasul - rasul Allah dan membiasakan perilaku terpuji, semestinya siswa dituntut untut dapat memahami materi tersebut.Namun yang terjadi adalah siswa belum maksimal untuk memahaminya dikarenakan kurangnya keaktifan siswa di kelas dan juga konsep pembelajaran yang tercipta di kelas.

Guru Pendidikan agama Islam seharusnya menciptakan kondisi belajar yang aktif untuk membantu siswa dalam belajar di kelas, khususnya mempelajari materi meningkatkan keimanan kepada rasul - rasul Allah dan membiasakan perilaku terpuji.

Selama proses belajar mengajar, penulis selaku guru bidang studi Pendidikan Agama Islam telah menggunakan Kurikulum Tingkat Satuan Pendidikan (KTSP) 2006 dalam proses belajar mengajar untuk kelas XI. Tetapi, dalam mengajar penulis cenderung masih bersifat konvensional, penulis memberi penjelasan dan siswa mencatat disertai tanya jawab seperlunya kemudian dilanjutkan dengan latihan soal atau tugas. Hal ini dapat terlihat dari hasil observasi yang peneliti lakukan di kelas XI, penggunaan metode konvensial ini dapat menghambat daya kritis siswa. Dengan demikian, sulit bagi siswa untuk mengembangkan krativitas yang dimilikinya secara optimal. Proses pembelajaran demikian membuat siswa kurang berminat dalam belajar Pendidikan Agama Islam. Situasi dan kondisi pembelajaran tersebut berpengaruh pada tingkat pencapaian hasil belajar siswa.

Berdasarkan tes yang telah dilakukan oleh penulis kepada siswa sebanyak 5 soal, kesulitan siswa dalam memahami materi masih ditemukan. Sebanyak $87 \%$ siswa melakukan kesalahan dalam menjawab pertanyaan. Mereka hanya mendapatkan nilai di bawah 75, sehingga tidak mencapai Kriteria Ketuntasan Minimum (KKM); di atas 75.Hanya $13 \%$ siswa yang mampu menjawab pertanyaan. Mereka kesulitan dalam menjawab pertanyaan karena mereka tidak perhatian penuh ketika proses belajar di kelas.

Dari hasil belajar di atas dapat disimpulkan bahwa hasil belajar siswa masuk dalam kategori kurang. Setelah ditelusuri dari resume pembelajaran yang dibuat pada setiap pertemuan, penyebab munculnya permasalahan di atas yaitu: 1) materi meningkatkan keimanan kepada rasul - rasul Allah dan membiasakan perilaku terpuji pada mata pelajaran Pendidikan Agama Islam sulit dipahami yang telah dapat dilihat dari hasil penilaian siswa; 2) siswa jarang mengajukan pertanyaan, walaupun guru sering meminta agar siswa bertanya jika ada hal-hal yang belum jelas atau kurang paham; 3) kurangnya keberanian siswa untuk mengemukakan gagasan/pendapat dalam pembelajaran; 4) guru sudah melakukan proses mengajar dengan baik, namun guru masih belum menggunakan sebuah strategi dalam pembelajaran, siswa masih hanya sebatas menghafalkan materi yang ada dalam buku cetak.

Untuk mengatasi hal di atas, maka penulis mempertimbangkan model pembelajaran yang cocok dan menyenangkan, terutama untuk materi meningkatkan keimanan kepada rasul rasul Allah dan membiasakan perilaku terpuji. Salah satu model pembelajaran yang akan digunakan oleh penulis adalah menggunakan strategi Teams Games Tournamen (TGT) pada pembelajaran ekonomi untuk pokok bahasan pasar keuangan. Strategi Teams Games Tournamen (TGT) terdiri atas 4 langkah utama yang merupakan siklus regular dari aktivitas pembelajaran. Step 1 yaitu pengajaran, pada tahap ini guru menyampaikan materi pelajaran. Step 2 yaitu belajar tim, para siswa 
mengerjakan lembar kegiatan dalam tim mereka untuk menguasai materi. Step 3 yaitu turnamen, para siswa memainkan game akademik dalam kemampuan yang homogen, dengan meja turnamen tiga peserta (kompetisi dengan tiga peserta). Step 4 yaitu rekognisi tim, skor tim dihitung berdasarkan skor turnamen anggota tim, dan tim tersebut akan direkognisi apabila mereka berhasil melampaui kriteria yang telah ditetapkan sebelumnya.

Berdasarkan penjelasan di atas, penulis tertarik untuk membuat penelitian yang berjudul "Penggunakan Strategi Teams Games Tournamen (TGT) untuk Meningkatkan HasilBelajar Pendidikan Agama Islam (PAI)Siswa Kelas XI IPS 3 SMA Negeri 1 Salo Tahun Pelajaran 2016/2017'.

\section{DESAIN PENELITIAN}

Penelitian ini merupakan Penelitian Tindakan Kelas (PTK). Menurut Kunandar (2011: 13), PTK adalah suatu penelitian tindakan yang dilakukan oleh guru sekaligus peneliti di kelasnya dengan merancang, melaksanakan tindakan, dan merefleksikannya dengan tujuan memperbaiki dan meningkatkan mutu pembelajaran.

Subjek penelitian ini adalah siswa kelas XI IPS 3 SMA Negeri 1 Salo 2016/2017. Siswa pada kelas ini terdiri dari 23 siswa.

Setting penelitian ini dilakukan pada kelas XI IPS 3 tahun pelajaran 2016 /2017 pada semester ganjil sesuai dengan program tahunan, dan program semester yang direncanakan oleh peneliti selaku guru mata pelajaran.
Parameter yang diukur dalam penelitian, yakni:

1. Parameter Utama

Parameter utama dalam penelitian berupa hasil belajar siswa yang terdiri dari daya serap dan ketuntasan siswa.

2. Parameter Pendukung

Parameter pendukung dalam penelitian ini adalah berupa hasil pengamatan aktivitas guru dan siswa dalam pelaksanaan tindakan.

\section{Instrumen Penelitian}

Instrumen penelitian adalah alat pengukur parameter. Dalam penelitian ini, ada dua instrumen penelitian, yaitu:

1. Test hasil belajar untuk mengukur daya serap siswa dan ketuntasan belajar siswa). Dalam hal ini instrumen yang digunakan adalah berupa post tespada akhir setiap pertemuan.

2. Lembar observasi aktivitas siswa berupa mengetahui materi, mengerjakan lembar kegiatan, dan memainkan game akademik. Sedangkan lembar observasi aktivitas guru yang diamati meliputi pendahuluan, kegiatan inti, dan penutup.

\section{HASIL DAN PEMBAHASAN \\ Hasil Tes}

Nilai - nilai hasil tes pada pratindakan, siklus I, dan siklus II secara prosentasi tergambar pada tabel berikut :

Tabel Perbandingan Nilai Siswa

\begin{tabular}{lllll}
\hline Nilai & \multicolumn{1}{c}{$\begin{array}{c}\text { Persentase } \\
\text { Pratindakan }\end{array}$} & \multicolumn{1}{c}{$\begin{array}{c}\text { Persentase Siklus } \\
\text { I }\end{array}$} & $\begin{array}{c}\text { Persentase Siklus } \\
\text { II }\end{array}$ & \multicolumn{1}{c}{$\begin{array}{c}\text { Tingkat } \\
\text { Kemampuan }\end{array}$} \\
\hline $81-100$ & $0 \%$ & $0 \%$ & $0 \%$ & Baik Sekali \\
\hline $61-80$ & $13,04 \%$ & $47,82 \%$ & $78 \%$ & Baik \\
\hline $41-60$ & $26,09 \%$ & $52,18 \%$ & $22 \%$ & Cukup \\
\hline $21-40$ & $47,83 \%$ & $0 \%$ & $0 \%$ & Kurang \\
\hline $0-20$ & $13,04 \%$ & $0 \%$ & $0 \%$ & Sangat Kurang \\
\hline Jumlah & $100 \%$ & $100 \%$ & $100 \%$ & \\
\hline
\end{tabular}


Dari nilai hasil tes pada pratindakan, siklus 1, dan siklus 2, siswa dengan kemampuan baik sekali hanya $0 \%$.

Siswa dengan kemampuan baik, pada pratindakan sebesar $13,04 \%$, pada siklus I sebesar 47,82\%, dan pada siklus II sebesar $78 \%$. Terjadi peningkatan dari pratindakan ke siklus I sebesar $34,781 \%$, dari siklus I ke siklus II sebesar 30,18\%.

Siswa dengan kemampuan cukup, pada pratindakan sebesar $26,09 \%$, pada siklus
I sebesar 52,18\%, dan siklus II sebesar $22 \%$. Terjadi penurunan persentase darisiklus I ke siklus II sebesar 30,18\%, artinya siswa yang memperoleh nilai cukup berkurang jumlahnya.

Siswa dengan kemampuan kurang dan sangat kurang, mengalami penurunan, dari pratindakan ke siklus I dan siklus II dari 13,04\% menjadi 0\% pada siklus I dan siklus II.

\section{Hasil Nontes}

\section{Nilai Aktivitas Siswa pada Siklus 1}

Tabel Aktivitas Siswa Siklus 1

\begin{tabular}{|c|l|c|c|c|c|c|c|}
\hline \multirow{2}{*}{ No } & \multicolumn{2}{|c|}{ Aktivitas Siswa } & \multicolumn{2}{c|}{ Pertemuan 1 } & \multicolumn{2}{c|}{ Pertemuan 2 } & \multicolumn{2}{c|}{ Pertemuan 3 } \\
\cline { 2 - 8 } & \multicolumn{2}{|l|}{$\mathbf{F}$} & $\mathbf{P ( \% )}$ & $\mathbf{F}$ & $\mathbf{P ( \% )}$ & $\mathbf{F}$ & $\mathbf{P ( \% )}$ \\
\hline $\mathbf{1}$ & Mengetahui Materi & 10 & $43 \%$ & 12 & $55 \%$ & 14 & $64 \%$ \\
\hline $\mathbf{2}$ & $\begin{array}{l}\text { Mengerjakan Lembar } \\
\text { Kegiatan }\end{array}$ & 16 & $70 \%$ & 17 & $77 \%$ & 18 & $82 \%$ \\
\hline $\mathbf{3}$ & $\begin{array}{l}\text { Memainkan } \\
\text { Akademik }\end{array}$ & 18 & $78 \%$ & 19 & $86 \%$ & 19 & $86 \%$ \\
\hline
\end{tabular}

Nilai aktivitas siswa pada siklus 1 yang terdiri dari pertemuan 1 , pertemuan 2 dan pertemuan 3. Ada 3 aktivitas siswa; mengetahui materi, mengerjakan lembar kegiatan, dan memainkan game akademik. Pada pertemuan 1, ada 10 siswa (43\%) mampu mengetahui materi, 16 siswa $(70 \%)$ mampu mengerjakan lembar kegiatan, dan 18 siswa (78\%) mampu memainkan game akademik. Pada pertemuan 2, ada 12 siswa (55\%) mampu mengetahui materi, 17 siswa (77\%) mampu mengerjakan lembar kegiatan, dan 19 siswa (86\%) mampu memainkan game akademik. Pada pertemuan 3, ada 14 siswa (64\%) mampu mengetahui materi, 18 siswa (82\%) mampu mengerjakan lembar kegiatan, dan 19 siswa (86\%) mampu memainkan game akademik. Dari tabel di atas, terjadi peningkatan aktivitas siswa dari pertemuan 1 ke pertemuan 2, dan dari pertemuan 2 ke pertemuan 3 .

\section{Nilai Aktivitas Siswa pada Siklus 2}

Tabel Aktivitas Siswa pada Siklus 2

\begin{tabular}{|c|l|c|c|c|c|c|c|}
\hline \multirow{2}{*}{ No } & \multicolumn{2}{|c|}{ Aktivitas Siswa } & \multicolumn{2}{c|}{ Pertemuan 4 } & \multicolumn{2}{c|}{ Pertemuan 5 } & \multicolumn{2}{c|}{ Pertemuan 6 } \\
\cline { 3 - 8 } & \multicolumn{2}{|l|}{$\mathbf{F}$} & $\mathbf{P ( \% )}$ & $\mathbf{F}$ & $\mathbf{P ( \% )}$ & $\mathbf{F}$ & $\mathbf{P ( \% )}$ \\
\hline $\mathbf{1}$ & Mengetahui Materi & 16 & $73 \%$ & 18 & $78 \%$ & 20 & $87 \%$ \\
\hline $\mathbf{2}$ & $\begin{array}{l}\text { Mengerjakan Lembar } \\
\text { Kegiatan }\end{array}$ & 20 & $91 \%$ & 22 & $96 \%$ & 22 & $96 \%$ \\
\hline $\mathbf{3}$ & $\begin{array}{l}\text { Memainkan Game } \\
\text { Akademik }\end{array}$ & 20 & $91 \%$ & 22 & $96 \%$ & 22 & $96 \%$ \\
\hline
\end{tabular}

Nilai aktivitas siswa pada siklus 2 yang terdiri pertemuan 4 , pertemuan 5 , dan pertemuan 6. Ada 3 aktivitas siswa; mengetahui materi, mengerjakan lembar kegiatan, dan memainkan game akademik. Pada pertemuan 4, ada 16 siswa $(73 \%)$ mampu mengetahui materi, 20 siswa (91\%) mampu mengerjakan lembar 
kegiatan, dan 20 siswa (91\%) mampu memainkan game akademik. Pada pertemuan 5, ada 18 siswa (78\%) mampu mengetahui materi, 22 siswa (96\%) mampu mengerjakan lembar kegiatan, dan 22 siswa (96\%) mampu memainkan game akademik. Dengan demikian, ada peningkatkan nilai aktivitas siswa dari pertemuan 4 ke pertemuan 6 pada siklus 2.

\section{KESIMPULAN}

Berdasarkan hasil data analisis di bab IV, penulis membuat kesimpulan sebagai berikut:

1. Hasil nilai rata-rata pada pratindakan adalah 47,83. Hasilbelajar PAI untuk siswa berada pada tingkat kemampuan kurang.

2. Setelah melakukan siklus 1, hasil nilai rata-rata siswa meningkat menjadi 52,18. Hal ini berarti kemampuan belajar PAI untuk siswa berada pada tingkat kemampuan cukup. Pada siklus 2, hasil nilai rata-rata siswa meningkat lagi menjadi 78. Hal ini berarti kemampuan belajar PAI untuk siswa berada pada tingkat kemampuan baik. Nilai tersebut lebih tinggi dari standar Kriteria Ketuntasan Minimal (KKM); diatas 75.

3. Data menunjukkan bahwa penggunaan strategi Teams Games Tournamen (TGT)dapat meningkatkan kemampuan siswa kelas XI IPS 3 SMA Negeri 1 Salodalam belajar PAI. Dengan kata lain, strategi tersebut dapat digunakan sebagai sebuah strategi dalam mengajarkan PAIuntuk meningkatkan pemahaman siswa dalam pelajaran tersebut.

Telah dibuktikan bahwa penggunaan strategi Teams Games Tournamen (TGT)dapat meningkatkan kemampuan siswa kelas XI IPS 3 SMA Negeri 1 Salo dapat mencapai Kriteria Ketuntasan Minimal (KKM) mata pelajaran PAI yang telah ditentukan. Sehingga, dapat disimpulkan bahwa penggunaan strategi Teams Games Tournamen (TGT) dapat meningkatkan kemampuan belajar PAI untuk siswa kelas XI IPS 3 SMA Negeri 1 Salo.

\section{Saran}

Ada beberapa saran yang dapat membantu guru dan guru pemula dalam mengajarkan PAI yang dapat dilihat sebagai berikut:

1. Seorang guru seharusnya membuat usaha yang lebih untuk meningkatkan kemampuan dan kualitasnya dalam mengajarkan PAI. Guru seharusnya dapat memperhatikan partisipasi siswa dalam proses belajar tersebut.

2. Seorang guru seharusnya mengetahui strategi mengajar yang cocok untuk memotivasi siswa dalam proses belajar mengajar.

Siswa dibutuhkan lebih banyak latihan dalam belajar PAIdi kelas maupun di luar kelas.

\section{DAFTAR PUSTAKA}

Anonim. 2015. Pengertian Hasil Belajar Siswa. www. landasan teori.com/2015/09/pengertian hasil - belajar - siswa definisi.html. 12 Agustus 2016

Al Fadhil,W.2011. Iman Kepada Rasul Allah SWT.https://paissmpn4 skl.wordpress.com/2011/04/12/ima n - kepada - rasul - allah - swt/. 10 Agustus 2016

Ami Rizky. 2012. Model Pembelajaran Kooperatif Tipe Teams Games Tournament.

rizardian.blogspot.co.id/2012/11/ model - pembelajaran - kooperatif - tipe - teams - games tournament.html. 12 Agustus 2016. 
Kunandar, 2011.Langkah Mudah

Penelitian Tindakan Kelas

Sebagai Pengembangan Profesi

Guru. PT Raja Grafindo Persada:

Jakarta

Nurkancana dan Sunartana. 1986. Evaluasi

Pendidikan. Surabaya: Usaha

Nasional.

Sanjaya Wina. 2009. Penelitian Tindakan

Kelas. Jakarta: Kencana Prenada

Media Group.

Stanley, dkk. 1988. Way to Writing. New

York: Mackmillan Publishing

Company. 
